\title{
Small mammals of the suburban areas of Warsaw in the diet of the tawny owl Strix aluco*
}

\section{Drobne ssaki terenów podmiejskich Warszawy w pokarmie puszczyka Strix aluco}

\author{
Jerzy Romanowski ${ }^{1}$, Grzegorz Lesiński ${ }^{2}$, Marta Bardzińska ${ }^{1}$ \\ ${ }^{1}$ Faculty of Biology and Environmental Sciences, Cardinal Stefan Wyszyński University in Warsaw, Poland \\ ${ }^{2}$ Faculty of Animal Sciences, Warsaw University of Life Sciences - SGGW, Poland \\ ORCID: JR https://orcid.org/0000-0003-1050-6403; GL https://orcid.org/ 0000-0003-3471-4821 • j.romanowski@uksw.edu.pl
}

\begin{abstract}
We investigated the composition of small mammals at nine locations in the southwestern suburban zone of Warsaw (central Poland) through the analysis of the pellets of the Tawny owl Strix aluco. In total, we recorded 611 individuals of 15 species of small mammal communities in the diet. Rodents constituted the most numerous mammalian order. Among the most abundant prey we recorded were Myodes glareolus ( 63 individuals $=10.3 \%$ of all mammals), Apodemus agrarius ( 56 individuals $=9.2 \%$ ) (173), Apodemus flavicollis (54 individuals $=8.8 \%$ ), Mus musculus (48 individuals $=7.9 \%$ ) and Microtus arvalis (44 individuals $=7.2 \%)$. We recorded also some species rarely captured by the tawny owl: Nyctalus noctula and Mustela nivalis. Species composition of small mammals of the study area resembled city parks, with several species typical for anthropogenic landscape.
\end{abstract}

Keywords: Rodentia, Soricomorpha, Chiroptera, owl pellets, anthropogenic landscape

Streszczenie: Zbadano skład zgrupowania drobnych ssaków na 9 stanowiskach położonych w podmiejskiej, południowo-zachodniej strefie Warszawy. Na podstawie analizy wypluwek puszzzyka Strix aluco stwierdzono łązznie 611 osobników reprezentujących 15 gatunków drobnych ssaków, głównie gryzoni. Do najilizniejszych gatunków należały: nornica ruda Myodes glareolus (63 osobniki), mysz polna Apodemus agrarius (56), mysz leśna Apodemus flavicollis (54), mysz domowa Mus musculus (48) i nornik zwyczajny Microtus arvalis (44). Stwierdzono gatunki rzadko łowione przez puszczyka: borowca wielkiego Nyctalus noctula i łasicę łaskę Mustela nivalis. W porównaniu do teriofauny Kampinoskiego Parku Narodowego, badane zgrupowanie drobnych ssaków cechuje zubożony skład gatunkowy. Jest ono nieco bardziej podobne do zgrupowań zasiedlających miejskie parki, niż do stwierdzonych w Chojnowskim Parku Krajobrazowym. Na terenie badań ponad 25\% oznaczonych do gatunku ssaków stanowily gryzonie charakterystyczne dla krajobrazu silnie przekształconego przez człowieka.

Słowa kluczowe: gryzonie, ryjówkokształtne, nietoperze, wypluwki sów, krajobraz antropogenicznie przekształcony

\section{Introduction}

Studies of the content of pellets of Strigiformes owls are especially often used to describe a diversity of species of small mammals (Żmihorski et al. 2008; 2011). An analysis of the results of numerous studies where two methods were used in parallel: catching into live traps and testing the contents of pellets of owls, indicated greater effectiveness of the second method for the description of small mammal communities (Heisler et al. 2015). In Poland, the studies based on the analysis of the contents of pel- lets of owls provided data for atlases of occurrence of mammals (Pucek and Raczyński 1983; Atlas ssaków Polski 2015). In the Mazowsze region, the analyses of food of the

\footnotetext{
"This article was originally published in Polish as Romanowski, Jerzy, Grzegorz Lesiński, i Marta Bardzińska. 2016. "Drobne ssaki terenów podmiejskich Warszawy w pokarmie puszczyka Strix aluco." Studia Ecologiae et Bioethicae 14(2): 105-113. The translation of the article into English was financed by the Ministry of Science and Higher Education of the Republic of Poland as part of the activities promoting science - Decision No. 676/P-DUN/2019 of 2 April 2019. Translation made by GROY Translations.
} 
tawny owl Strix aluco were used to characterise small mammals of Kampinos National Park (Lesiński et al. 2013) and Chojnów Landscape Park (Romanowski et al. 2014), as well as of the urban agglomeration of Warsaw and its immediate neighbourhood (Goszczyński et al. 1993; Lesinski and Stolarz 1999; Gryz et al. 2008; Lesiński and Gryz 2011 Stolarz and Lesiński 2012). The purpose of this study is to analyse the diet of the tawny owl and to describe the species composition of a small mammal community in the south-western part of suburban areas of Warsaw.

\section{Area and research methods}

The research was carried out in the suburban areas of Warsaw located south-west of urban agglomeration. The area is largely urbanised (buildings occupy approx. $35 \%$ of the area) and performs various functions, among other things, residential, economic, transit, recreational and agricultural, typical for the fast-growing suburban area surrounding Warsaw. Agricultural land and woodland are largely fragmented by buildings and an extensive network of roads.

The research material was collected from 1995 to 2015 (mostly from 2010 to 2015) from nine study sites (Table 1). The pellets were collected mainly during the inspection of nesting boxes of the tawny owl, as well as found under trees and hollows occupied by owls. The areas of the collection of the material were located in the urban

Table 1. Location of the study sites for the collection of pellets of a tawny owl Strix aluco in the south-west region of the suburbs of Warsaw.

\begin{tabular}{|c|c|c|c|c|}
\hline Study site & $\begin{array}{c}\text { Location } \\
\text { geographical }\end{array}$ & $\begin{array}{l}\text { Environment } \\
\text { type }\end{array}$ & $\begin{array}{c}\text { Area of collection } \\
\text { of pellets }\end{array}$ & $\begin{array}{l}\text { Period } \\
\text { of study }\end{array}$ \\
\hline Kraśnicza Wola & $52^{\circ} 07^{\prime} \mathrm{N}, 21^{\circ} 03^{\prime} \mathrm{E}$ & $\begin{array}{l}\text { woodland near } \\
\text { ponds fish }\end{array}$ & nesting box & 2011-2015 \\
\hline Milanówek & $52^{\circ} 07^{\prime} \mathrm{N}, 20^{\circ} 40^{\prime} \mathrm{E}$ & development & nesting box & 2013 \\
\hline Ojrzanów & $52^{\circ} 01^{\prime} \mathrm{N}, 20^{\circ} 44^{\prime} \mathrm{E}$ & single family park & under trees & 1995 \\
\hline Podkowa Leśna & $52^{\circ} 07^{\prime} \mathrm{N}, 20^{\circ} 42^{\prime} \mathrm{E}$ & suburban forest & tree hollow & 2010-2014 \\
\hline Pruszków & $52^{\circ} 09^{\prime} \mathrm{N}, 20^{\circ} 48^{\prime} \mathrm{E}$ & park & nesting box & 2010 \\
\hline Raszyn & $52^{\circ} 08^{\prime} \mathrm{N}, 20^{\circ} 55^{\prime} \mathrm{E}$ & park & under trees, & 2012-2013 \\
\hline Seroki Parcele & $52^{\circ} 12^{\prime} \mathrm{N}, 20^{\circ} 27^{\prime} \mathrm{E}$ & park & $\begin{array}{l}\text { tree hollow } \\
\text { nesting box }\end{array}$ & 2012 \\
\hline Zalesie Dolne & $52^{\circ} 04^{\prime} \mathrm{N}, 21^{\circ} 01^{\prime} \mathrm{E}$ & $\begin{array}{l}\text { building } \\
\text { on the edge } \\
\text { of the forest }\end{array}$ & under trees & 2015 \\
\hline Złotokłos & $52^{\circ} 01^{\prime} \mathrm{N}, 20^{\circ} 54^{\prime} \mathrm{E}$ & plots recreational & nesting box & $2006-2009$ \\
\hline
\end{tabular}


area ( 2 working sites), in parks and urban woodlands (5), recreation plots (1) and woodlands at the edge of fish ponds (1).

The analysis of the composition of the pellets was performed according to a standard methodology (Raczyński and Ruprecht 1974). Pellets and shredded material found in boxes, containing the remains of prey of tawny owls, were soaked in water and rinsed using a sieve. Each separate pellet was analysed individually. The mammals were identified using the mammal identification key of Poland (Pucek 1984) and a comparative collection of skulls. The number of mammals was determined based on the maximum number of left and right jaw bones and skulls. The number of characteristic humerus bones of a mole Talpa europaea was also analysed, as well as beaks and humerus bones of birds Aves and hip bones os ilium of amphibians. Fish Osteichthies were determined based on the presence of bones and scales. The results were presented as the share of individual species in the eaten prey.
In order to refer collected examination results to studies in other environments, the share of small mammal species associated with environments heavily transformed by a man (Microtus arvalis, Mus musculus, Rattus norvegicus) was compared to a share of species associated with natural and forest environments (Microtus oeconomus, Myodes glareolus, Apodemus flavicollis).

\section{Results}

A total number of 920 species were identified in the analysed material, including 611 (66.4\%) mammals Mammalia, 86 (9.0\%) birds, 225 (24.5\%) amphibians Anura and $1(0.1 \%)$ fish. Fifteen species of mammals have been identified, representing four orders: shrew-form Soricomorpha, bats Chiroptera, rodents Rodentia, and carnivores Carnivora (Table 2). The most numerous (10 species) group of mammals in the studied area were rodents, recorded in the diet of the tawny owl at all working sites. The most commonly caught species were:

Table 2. The number of individuals of small mammals Micromammalia in food of the tawny owl Strix aluco at each study site in the suburban zone of Warsaw. \% - percentage in the number of captured mammals. 1 - Kraśnicza Wola, 2 - Milanówek, 3 - Ojrzanów, 4 - Podkowa Leśna, 5 - Pruszków, 6 - Raszyn, 7 - Seroki Parcele, 8 - Zalesie Dolne, 9- Złotokłos.

\begin{tabular}{|c|c|c|c|c|c|c|c|c|c|c|}
\hline \multirow[t]{2}{*}{ Species } & \multicolumn{10}{|c|}{ Working site } \\
\hline & 1 & 2 & 3 & 4 & 5 & 6 & 7 & 8 & 9 & Total (\%) \\
\hline European mole Talpa Europaea & 1 & 1 & 0 & 6 & 0 & 1 & 0 & 0 & 0 & $9(1.5)$ \\
\hline Common shrew Sorex araneus & 2 & 0 & 0 & 18 & 1 & 5 & 1 & 0 & 3 & $30(4.9)$ \\
\hline Pygmy shrew Sorex minutus & 1 & 0 & 0 & 0 & 0 & 0 & 0 & 0 & 0 & $1(0.2)$ \\
\hline Common noctule Nyctalus noctula & 0 & 0 & 0 & 1 & 4 & 0 & 0 & 1 & 0 & $6(1.0)$ \\
\hline Bank vole Myodes glareolus & 32 & 0 & 6 & 16 & 0 & 8 & 0 & 0 & 1 & $63(10.3)$ \\
\hline European pine vole Microtus subterraneus & 1 & 0 & 0 & 0 & 1 & 1 & 0 & 0 & 0 & $3(0.5)$ \\
\hline Tundra vole Microtus oeconomus & 9 & 0 & 0 & 0 & 0 & 0 & 2 & 0 & 0 & $11(1.8)$ \\
\hline Common vole Microtus arvalis & 22 & 1 & 0 & 1 & 5 & 4 & 4 & 0 & 7 & $44(7.2)$ \\
\hline unspecified vole Microtus sp. & 1 & 1 & 0 & 0 & 0 & 1 & 3 & 0 & 4 & $7(1.1)$ \\
\hline House mouse Mus musculus & 20 & 0 & 0 & 0 & 3 & 4 & 0 & 0 & 21 & $48(7.9)$ \\
\hline Brown rat Rattus norvegicus & 10 & 0 & 0 & 0 & 3 & 2 & 2 & 0 & 1 & $18(2.9)$ \\
\hline Harvest mouse Micromys minutus & 27 & 0 & 1 & 1 & 3 & 3 & 3 & 0 & 0 & $38(6.2)$ \\
\hline Striped field mouse Apodemus agrarius & 29 & 0 & 6 & 3 & 6 & 5 & 6 & 0 & 1 & $56(9.2)$ \\
\hline Wood mouse Apodemus sylvaticus & 0 & 0 & 0 & 0 & 0 & 1 & 0 & 0 & 0 & $1(0.2)$ \\
\hline Yellow-necked mouse Apodemus flavicollis & 23 & 0 & 0 & 24 & 0 & 2 & 1 & 3 & 1 & $54(8.8)$ \\
\hline Unspecified mouse Apodemus sp & 83 & 5 & 3 & 26 & 32 & 13 & 51 & 2 & 6 & $221(36.2)$ \\
\hline Least weasel Mustela nivalis & 0 & 0 & 0 & 0 & 0 & 0 & 0 & 1 & 0 & $1(0.2)$ \\
\hline Total mammals & 261 & 8 & 16 & 96 & 58 & 50 & 70 & 7 & 45 & $611(100.0)$ \\
\hline
\end{tabular}


the bank vole Myodes glareolus (10.3\% of caught mammals), a field mouse Apodemus agrarius (9.2\%), a yellow-necked mouse Apodemus flavicollis (8.8\%), as well as a house mouse Mus musculus (7.9\%) and common voles Microtus arvalis (7.2\%). The harvest mouse Micromys minutus was also quite common in food (6.2\%). The most common among the shrew - shaped species caught by the owl was the common shrew Sorex araneus (4.9\%), less frequently the mole (1.5\%), and also one pygmy shrew Sorex minutus (in Kraśniczna Wola). In three working sites, in the pellets of the tawny owl the common noctule Nyctalus noctula was found: in Podkowa Leśna (1 individual), Pruszków (4 individuals) and Zalesie Dolne (1 individual). It is worth noting that the least weasel Mustela nivalis was found in material from Zalesie Dolne.

The found species of small mammals are mainly associated with a forest habitat (bank vole, yellow-necked mouse, common noctule), agricultural areas (voles), as well as areas heavily transformed by a man (house mouse, the wild brown rat Rattus norvegicus).

\section{Discussion}

The collected material did not show a dominance of mammal species associated with a specific environment, for instance, woodland or agricultural. The proportion of species representing a typical habitat in the heavily transformed suburban landscape was regular. The described species of small mammals belong to fairly common groups of species recorded in Poland (Pucek and Raczyński 1983; Atlas ssaków Polski 2015).

The group of small mammals presented in this study is significantly poorer in the numbers of species than those recorded in the nearby Kampinos National Park. The analysis of food of the tawny owl in this park revealed a presence of 29 species, including 9 bats and 14 rodents (Lesinski et al. 2013). Similarly to current studies, several dozen of species of mammals were recorded in the food of the tawny owl in Warsaw parks (Goszczyński et al. 1993; Gryz et al. 2008) and in Chojnowski Landscape Park (Romanowski et al. 2014). It is worth noting, however, that in the latter area, there were several species noted in the group of mammals rarely caught by the tawny owl (for example three species of bats and the Eurasian water shrew Neomys fodiens).

A comparison of the frequency of catching by the tawny owl two groups of species associated with the anthropogenic landscape in three areas (Warsaw, Chojnowski Landscape Park and the area of our research) showed significant differences (Table 3). In Warsaw, the species inhabiting environments strongly transformed by a man gained a significant advantage, while in Chojnów Landscape Park, the share of species typical for natural areas (forests) was significantly higher. The suburban areas of Warsaw are characterised by a relatively high proportion of anthropogenic landscape species. In the subur-

Table 3. A comparison of the proportion of mammal species caught by the tawny owl in highly human - transformed environments (Microtus arvalis, Mus musculus, Rattus norvegicus - Group A) to the number of mammal species in natural environments (Microtus oeconomus, Myodes glareolus, Apodemus flavicollis - Group B).

\begin{tabular}{|l|c|c|c|c|}
\hline Test area & $\begin{array}{c}\text { Number of mammals } \\
\text { in Group A }\end{array}$ & $\begin{array}{c}\text { Number of mammals } \\
\text { in Group B }\end{array}$ & A / B & Data source \\
\hline Warsaw & 382 & 21 & 18.2 & Goszczyński \\
\hline Suburban areas & 110 & 128 & 0.9 & $\begin{array}{c}\text { et al. 1993 } \\
\text { this study }\end{array}$ \\
\hline Warsaw Chojnowski Park & 32 & 483 & 0.1 & Romanowski \\
\hline Landscape & & & & et al. 2014 \\
\hline
\end{tabular}


ban forest, Sobieski forest (Las Sobieskiego), which is connected to the non-urban forests, a high proportion of species which do not penetrate the city was recorded, for instance, a velvet shrew and the bank vole, while a low proportion (approx. 2\%) of synanthropic species (house mouse and the brown rat) (Lesiński and Carpenter 1999). It is worth noting that a higher proportion of species inhabiting the natural environment was recorded in the diet of the tawny owl in the agricultural landscape of northern Podlasie (Lesiński et al. 2009).

\section{Conclusions}

The composition of a group of small mammals was examined in 9 study sites located in the suburban, south-western zone of Warsaw. A total of 611 individuals representing 15 species of small mammals, mostly rodents, were identified based on an analysis of pellets of the tawny owl Strix aluco. The most numerous groups of species were: the bank vole Myodes glareolus (63 individuals), the striped field mouse Apodemus agrarius (56), the yellow-necked mouse Apodemus flavicollis (54), house mouse Mus musculus (48) and the common vole Microtus arvalis (44). The species rarely caught by the tawny owl were: the common noctule Nyctalus noctula and the common weasel Mustela nivalis. Compared to the teriofauna of Kampinos National Park, the studied group of small mammals is characterised by a depleted composition of species. It is a bit more similar to the groups inhabiting urban parks rather than to those found in Chojnowski Landscape Park. In the area of this study, more than $25 \%$ of identified species of mammals were rodents characteristic for a landscape heavily transformed by man.

Acknowledgements: The authors would like to thank: Maria Łepkowska, Ireneusz Mirowski, Adam Olszewski and Adam Tarłowski for their participation in the collection of the material, as well as Adam Prokopowicz and Alicja Gadomska for their assistance in the laboratory work.

\section{Bibliography}

Atlas ssaków Polski. 2015. Kraków: Instytut Ochrony Przyrody PAN. Dostęp: 20.06.2015. http://www.iop.krakow.pl/ssaki/.

Goszczyński, Jacek, Piotr Jabłoński, Grzegorz Lesiński, and Jerzy Romanowski. 1993. "Variation in diet of Tawny Owl Strix aluco L. along an urbanization gradient." Acta Ornithologica 27(2): 113-123.

Gryz, Jakub, Dagny Krauze, and Jacek Goszczyński. 2008. "The small mammals of Warsaw as inferred from tawny owl (Strix aluco) pellet analyses." Annales Zoologici Fennici 45(4): 281-285.

Heisler, Leanne M., Christopher M. Somers, and Ray G. Poulin. 2015. "Owl pellets: a more effective alternative to conventional trapping for broad-scale studies of small mammal communities." Methods in Ecology and Evolution 7(1): 96-103. https://doi. org/10.1111/2041-210X.12454.

Lesiński, Grzegorz, Grzegorz Błachowski, and Marcin Siuchno 2009. „Vertebrates in the diet of the tawny owl Strix aluco in northern Podlasie (NE Poland) - comparison of forest and rural habitats." Fragmenta Faunistica 52(1): 51-59.

Lesiński, Grzegorz, and Jakub B. Gryz. 2012. "How protecting a suburban forest as a natural reserve effected small mammal communities." Urban Ecosystems 15(1): 103-110.

Lesiński, Grzegorz, Jerzy Romanowski, Jakub Gryz, Adam Olszewski, Kowalski Marek, Dagny Krauze-Gryz, Olech Bogumiła, Pepłowska-Marczak Danuta, and Adam Tarłowski. 2013. "Small mammals of Kampinos National Park and its protection zone, as revealed by analyses of the diet of tawny owls Strix aluco Linnaeus, 1758." Fragmenta Faunistica 56(1): 65-81.

Lesiński, Grzegorz, i Przemysław Stolarz. 1999. „Kręgowce w pokarmie puszczyka Strix aluco w Lesie Sobieskiego na peryferiach Warszawy." Kulon 1-2: 77-81.

Pucek, Zdzisław (red.). 1984. Klucz do oznaczania ssaków Polski. Warszawa: Wydawnictwo Naukowe PWN.

Pucek, Zdzisław, i Jan Raczyński (red.). 1983. Atlas rozmieszczenia ssaków w Polsce. Warszawa: Wydawnictwo Naukowe PWN.

Raczyński, Jan, and Andrzej L. Ruprecht. 1974. 
"The effect of digestion on the osteological composition of owl pellets." Acta Ornithologica 14(2): 25-38.

Romanowski, Jerzy, Adam Tarłowski, Grzegorz Lesiński, i Adam Olszewski. 2014. „Drobne ssaki Chojnowskiego Parku Krajobrazowego w pokarmie puszczyka Strix aluco." Chrońmy Przyrodę Ojczysta 70(1): 63-67.

Stolarz, Przemysław, i Grzegorz Lesiński. 2012. „Kręgowce w pokarmie puszczyka Strix alu$c o \mathrm{w}$ rezerwacie Bagno Jacka i na terenach przyległych." Kulon 17: 107-110.
Żmihorski, Michał, Laima Balčiauskienè, and Jerzy Romanowski. 2008. "Small mammals in the diet of the Tawny Owl (Strix aluco L.) in Central European lowland." Polish Journal of Ecology 56(4): 693-700.

Żmihorski, Michał, Jakub Gryz, Dagny KrauzeGryz, Anna Olczyk, and Grzegorz Osojca. 2011. „The Tawny owl Strix aluco as a material collector in faunistic investigations: the case study of small mammals in NE Poland." Acta Zoologica Lituanica 21(3): 185-191. 